\title{
Vector-Borne Pathogens with Veterinary and Public Health Significance in Melophagus ovinus (Sheep Ked) from the Qinghai-Tibet Plateau
}

\author{
Qing-Xun Zhang 1,2,+, Ye Wang 1,3,+, Ying Li 4,+, Shu-Yi Han ${ }^{1}$, Bo Wang 1,2, Guo-Hui Yuan ${ }^{1}$, Pei-Yang Zhang 1,2,

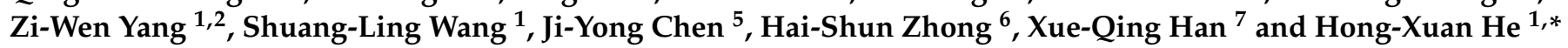 \\ check for \\ updates \\ 1 National Research Center for Wildlife-Born Diseases, Institute of Zoology, Chinese Academy of Sciences, \\ Beijing 100101, China; zhangqingxun@ioz.ac.cn (Q.-X.Z.); yew4315@126.com (Y.W.); \\ hanshuyi@ioz.ac.cn (S.-Y.H.); wangbo@ioz.ac.cn (B.W.); yuanguohui1022@163.com (G.-H.Y.); \\ zhangpeiyang@ioz.ac.cn (P.-Y.Z.); yangziwen@ioz.ac.cn (Z.-W.Y.); wangs10830@163.com (S.-L.W.) \\ 2 National Research Center for Wildlife-Born Diseases, University of Chinese Academy of Sciences, \\ Beijing 100049, China \\ 3 Ningxia University, Yinchuan 750021, China \\ 4 State Key Laboratory of Plateau Ecology and Agriculture, Qinghai University, Xining 810016, China; \\ yingli@126.com \\ 5 Animal Disease Prevention and Control Center of Yushu, Yushu 815099, China; 13997361966@163.com \\ 6 Animal Husbandry and Veterinary Station of Xunhua, Xunhua 811100, China; zhs9822@163.com \\ 7 Chinese Academy of Inspection and Quarantine, Beijing 100176, China; xqhancaiq@163.com \\ * Correspondence: hehx@ioz.ac.cn \\ + These authors contributed equally to this work and should be considered co-first authors.
}

Citation: Zhang, Q.-X.; Wang, Y.; Li, Y.; Han, S.-Y.; Wang, B.; Yuan, G.-H.; Zhang, P.-Y.; Yang, Z.-W.; Wang, S.-L.; Chen, J.-Y.; et al. Vector-Borne Pathogens with Veterinary and Public Health Significance in Melophagus ovinus (Sheep Ked) from the Qinghai-Tibet Plateau. Pathogens 2021, 10, 249. https://doi.org/10.3390/ pathogens10020249

Academic Editor: Xuenan Xuan

Received: 16 January 2021

Accepted: 19 February 2021

Published: 22 February 2021

Publisher's Note: MDPI stays neutral with regard to jurisdictional claims in published maps and institutional affiliations.

Copyright: (c) 2021 by the authors. Licensee MDPI, Basel, Switzerland. This article is an open access article distributed under the terms and conditions of the Creative Commons Attribution (CC BY) license (https:/ / creativecommons.org/licenses/by/ $4.0 /)$.

\begin{abstract}
Melophagus ovinus (sheep ked) is a hematophagous ectoparasite that mainly parasitizes sheep. In addition to causing inflammation, wool loss, and skin damage to the animal hosts, M. ovinus also serves as a vector for a variety of pathogens and is highly likely to participate in the life and transmission cycle of pathogenic organisms. Herein, we investigated the presence and molecular characterization of vector-borne pathogens in M. ovinus from Qinghai-Tibet Plateau, China. A total of $92 \mathrm{M}$. ovinus pools collected from the Qinghai province of China were screened for the presence of selected vector-borne pathogens. The overall positive rate of A. ovis, A. bovis, A. phagocytophilum, and T. ovis in M. ovinus was $39.1 \%, 17.4 \%, 9.8 \%$, and $89.1 \%$, respectively. All of the samples were negative for Border disease virus (BDV), other Anaplasma species, Babesia spp., Rickettsia spp., and Borrelia spp. Co-infection of different Anaplasma species and T. ovis occurred in $51.2 \%$ of all samples with T. ovis. The positive rates of $A$. ovis, $A$. bovis, and A. phagocytophilum in different regions and altitudes of the sampling sites were significantly different. Sequence and phylogenetic analysis of target genes confirmed their identity with corresponding pathogens. Our results elucidate the occurrence and molecular characterization of Anaplasma spp. and Theileria spp. in M. ovinus, which could act as potential zoonotic reservoirs. To the best of our knowledge, this is the first report of the detection of $A$. bovis and A. phagocytophilum DNA in M. ovinus. This study gives the first extensive molecular survey of vector-borne pathogens with veterinary and public health significance in $M$. ovinus from the Qinghai-Tibet Plateau, China.
\end{abstract}

Keywords: Melophagus ovinus; vector-borne pathogens; occurrence; reservoir; China

\section{Introduction}

Melophagus ovinus (sheep ked) belongs to the family Hippoboscidae (Diptera: Hippoboscoidea) and is a blood-feeding ectoparasite of livestock and wild animals, including sheep, goats, rabbits, dogs, Tibetan antelope, European bison, and red foxes, and has also been found in humans [1-3]. The life cycle of sheep ked comprises the larva, pupa, and wingless adult stages, and all life stages of this ectoparasite occur on the host. After mating, 
the females produced single larvae every 6-8 days that were attached to the host wool and molded into the puparial stage within 6-12 h. It takes the pupae 19-30 days to develop into an adult [3]. Adults are commonly circulated among the animals and transferred from ewes to their offspring by direct contact. Melophagus ovinus (M. ovinus) is reported to cause inflammation, wool loss, skin damage, and reductions in weight gain of sheep and has significant economic effects in the sheep industry [4,5]. Of the sheep studied, $61-81 \%$ of sheep were infested with M. ovinus [3]. Melophagus ovinus is broadly distributed in Africa, Europe, Oceania, North America, and Asia [5]. In China, M. ovinus has recently been reported to parasitize sheep and Tibetan antelopes in Tibet, Xinjiang, Qinghai, and Gansu, and was also detected in imported sheep and sheep wool in certain areas of China [6-8].

Melophagus ovinus serves as potential vectors of a variety of pathogens and has been reported to be responsible for the transmission of pathogenic organisms such as helminths, protozoa, bacteria, and viruses due to their blood-feeding behavior towards hosts $[1,9]$. M. ovinus was reported to mechanically transmit the Bluetongue virus in sheep [2]. Additionally, previous studies showed that M. ovinus may be a vector for Bartonella schoenbuchensis and B. chomeli in the USA [10], Anaplasma ovis in Hungary [11], Acinetobacter spp. in Ethiopia [12], and Bartonella in Central Europe [2]. Chu et al. [6] reported Borrelia burgdorferi sensu lato in sheep keds in Tibet, China. Recently, in China, Anaplasma ovis [13], Rickettsia raoultii and R. slovaca [5], Theileria ovis [9], and Border disease virus (BDV) [14] have also been detected in M. ovinus in the Xinjiang Uygur Autonomous Region of northwestern China.

The Qinghai province is one of the traditional animal husbandry bases in China and a small number of reports have recorded the presence of M. ovinus in the region [5]. However, very little is known about the occurrence of arthropod-borne pathogens in M. ovinus from the Qinghai. Given the veterinary and public health significance of M. ovinus, the objective of the present study was to investigate the presence of vector-borne pathogens in M. ovinus from the Qinghai-Tibet Plateau of China.

\section{Results}

A total of $92 \mathrm{M}$. ovinus pools were screened for the presence of selected vector-borne pathogens. Of the 92 samples tested, 46 (50.0\%) pools were positive for one or more Anaplasma species. The infection rates were $39.1 \%, 17.4 \%$, and $9.8 \%$ for Anaplasma ovis (A. ovis), Anaplasma bovis (A. bovis), and Anaplasma phagocytophilum (A. phagocytophilum) in $M$. ovinus, respectively (Table 1 ). Importantly, $A$. bovis, and A. phagocytophilum were detected in $M$. ovinus for the first time. A total of 82 pools (89.1\%) were positive for piroplasm infections, and all of which belonged to Theileria ovis (T. ovis). No positive results were obtained for other tested pathogens, including BDV, Anaplasma centrale, Anaplasma platys, Anaplasma capra, Anaplasma marginale, Babesia spp., Rickettsia spp., and Borrelia spp. Mixed infections of both the T. ovis and Anaplasma species accounted for $51.2 \%$ (42/82) of all samples with the T. ovis. Anaplasma ovis co-infections with $A$. bovis and A. phagocytophilum accounted for 26.1\% (12/46) and 2.2\% (1/46) of Anaplasma species infections, respectively. Sequence analysis of the msp4 sequences of $A$. ovis (sequence similarity $100 \%$ ), $16 \mathrm{~S}$ rRNA sequences of $A$. bovis (sequence similarity $99.9-100 \%$ ) and A. phagocytophilum (sequence similarity 100\%), and 18S rRNA gene sequences of T. ovis (sequence similarity 99.9-100\%) confirmed their identity with corresponding pathogens by using BLASTn search. Phylogenetic analysis of the msp4 sequences represented showed that the MW147462 sequence was classified as A. ovis Genotypes II based on nucleotide mutation sites $\left(\mathrm{A}^{360} \mathrm{~T}^{366} \mathrm{G}^{400}\right)$. Sequence MW142385 of A. phagocytophilum was classified into cluster I, and sequence MW142384 of $A$. bovis was identical with strains isolated from sheep (MT036513), tick (KC311345), horse (MK028574), and deer (KJ659040) (Figure 1A-C). The phylogenetic analysis of the 18S rRNA gene confirmed that the detected piroplasm (MW142379) was T. ovis (Figure 1D). 
Table 1. Detection of Anaplasma and Theileria pathogens in 92 ked pools at various geographic sites.

\begin{tabular}{cccccc}
\hline \multirow{2}{*}{$\begin{array}{c}\text { County/Average } \\
\text { Altitude }\end{array}$} & $\begin{array}{c}\text { Number } \\
\text { of Pooled }\end{array}$ & A. ovis & Number of Infected (n)/Infection Rate (\%) \\
\cline { 3 - 6 } & 8 & $6 / 75.0$ & $3 / 37.5$ & A. phagocytophilum & T. ovis \\
\hline Xunhua/3000 m & 37 & $10 / 27.0$ & $1 / 2.7$ & $1 / 12.5$ & $8 / 100$ \\
Maqin/3800 m & 15 & $4 / 26.7$ & $2 / 13.3$ & $0 / 0$ & $32 / 86.5$ \\
Dari/4100 m & 32 & $16 / 50.0$ & $10 / 31.3$ & $7 / 21.9$ & $28 / 87.5$ \\
Zhiduo/4100 m & 92 & $36 / 39.1$ & $16 / 17.4$ & $9 / 9.8$ & $82 / 89.1$ \\
\hline Total & & & &
\end{tabular}

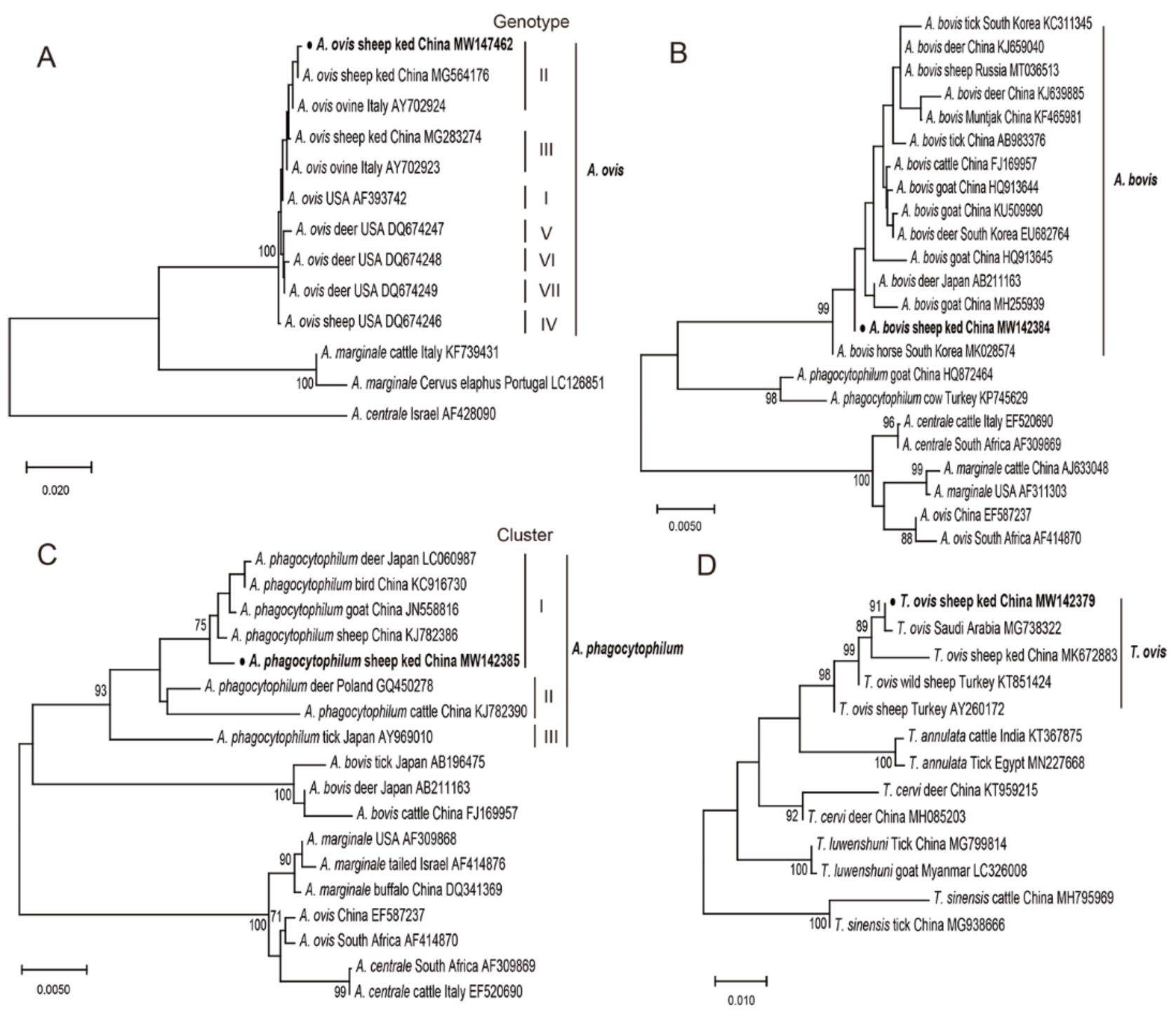

Figure 1. Phylogenetic relationship of partial segment msp4 of A. ovis (A), 16S rRNA gene for A. bovis (B), A. phagocytophilum $(\mathbf{C})$, and $18 \mathrm{~S}$ rRNA gene of T. ovis (D) identified in the present study and reference strains. All molecular phylogenetic trees were constructed by the neighbor-joining method with Kimura 2-parameter model using the MEGAX software, and the bootstrap test was assessed with 1000 replicates. The species identified in this study are indicated by $\bullet$ and highlighted in bold. 
Risk factors including M. ovinus gender, the region, and altitude of the sampling sites were used as variables for statistical analysis of the infection patterns of Anaplasma spp. and Theileria spp. occurrence (Table 2). For the occurrence of A. ovis, A. bovis, and A. phagocytophilum, significant differences between locations have been observed. Melophagus ovinus collected in Haidong had a higher risk than other M. ovinus in Golog and Yushu to be infected with $A$. ovis $(p=0.01)$ and $A$. bovis $(p=0.003)$, while $A$. phagocytophilum infection rate in M. ovinus collected in Yushu was significantly higher than Haidong and Golog ( $p=0.011$. Melophagus ovinus collected at $3000 \mathrm{~m}$ areas was at higher risk of being infected with A. ovis ( $p=0.033$ ) and A. bovis ( $p=0.007)$ than in M. ovinus collected at altitudes of $3800 \mathrm{~m}$ and $4100 \mathrm{~m}$. Besides, the results showed no significant difference in gender.

Table 2. Patterns of Anaplasma and Theileria pathogens positive rates in 92 M. ovinus pools, grouped by M. ovinus gender, the region, and altitude of the sampling sites.

\begin{tabular}{|c|c|c|c|c|c|c|c|c|c|c|}
\hline \multirow{2}{*}{ Group } & & \multirow{2}{*}{$\begin{array}{l}\text { Number } \\
\text { of Pooled }\end{array}$} & \multicolumn{8}{|c|}{ Number of Infected (n)/Infection Rate (\%) } \\
\hline & & & A. ovis & $p$-Value & A. bovis & $p$-Value & A. phagocytophilum & $p$-Value & T. ovis & $p$-Value \\
\hline \multirow{3}{*}{ Region } & Haidong & 8 & $6 / 75.0$ & \multirow{3}{*}{0.01} & $3 / 37.5$ & \multirow{3}{*}{0.003} & $1 / 12.5$ & \multirow{3}{*}{0.011} & $8 / 100$ & \multirow{3}{*}{0.581} \\
\hline & Golog & 52 & $14 / 26.9$ & & $3 / 5.8$ & & $1 / 1.9$ & & $46 / 88.5$ & \\
\hline & Yushu & 32 & $16 / 50.0$ & & $10 / 31.3$ & & $7 / 21.9$ & & $28 / 87.5$ & \\
\hline \multirow{2}{*}{ Gender } & Female & 41 & $18 / 43.9$ & \multirow{2}{*}{0.40} & $5 / 12.2$ & \multirow[b]{2}{*}{0.238} & $6 / 14.6$ & \multirow{2}{*}{0.160} & $36 / 87.8$ & \multirow[b]{2}{*}{0.714} \\
\hline & Male & 51 & $18 / 35.3$ & & $11 / 21.7$ & & $3 / 5.9$ & & $46 / 90.2$ & \\
\hline \multirow{3}{*}{ Altitude } & $3000 \mathrm{~m}$ & 8 & $6 / 75.0$ & \multirow{3}{*}{0.033} & $3 / 37.5$ & \multirow{3}{*}{0.007} & $1 / 12.5$ & \multirow{3}{*}{0.169} & $8 / 100$ & \multirow{3}{*}{0.537} \\
\hline & $3800 \mathrm{~m}$ & 37 & $10 / 27.0$ & & $1 / 2.7$ & & $1 / 2.7$ & & $32 / 86.5$ & \\
\hline & $4100 \mathrm{~m}$ & 47 & $20 / 42.6$ & & $12 / 25.5$ & & $7 / 14.9$ & & $42 / 89.4$ & \\
\hline
\end{tabular}

Bold typeface indicates significant difference.

\section{Discussion}

To date, few publications have described the distribution and prevalence of vectorborne pathogens in M. ovinus from the Qinghai-Tibet Plateau, China [5,6]. As the traditional animal husbandry base, epidemiological investigations into vector-borne pathogens with veterinary and public health significance in Qinghai are of particular importance. Anaplasma spp. occurrence in M. ovinus demonstrated a wide distribution of A. ovis, A. bovis, and A. phagocytophilum in the Qinghai-Tibet Plateau, China. A. ovis has been considered as the etiological agents of anaplasmosis of domestic ruminants and it has been widely detected in sheep, goats, wild deer, and many tick species around the world $[15,16]$. In previous reports, all sheep keds $(100 \%, 81 / 81)$ were found to harbor A. ovis in Hungary [11] and 28 specimens (including five pupal specimens) $(31.8 \%, 28 / 88)$ collected in 2016 and 2017 in Xinjiang, China tested positive for $A$. ovis [13]. The positive rate $(39.1 \%)$ and genetic characteristic (Genotype I) of $A$. ovis in M. ovinus in this study concurred with other reports published in Xinjiang.

To the best of our knowledge, this is the first molecular evidence of $A$. bovis and A. phagocytophilum in M. ovinus over the world. Anaplasma bovis mainly affects cattle with fever, progressive anemia, and even death, and the subclinical infections of this agent have also been found in small mammals and ruminants, indicating the reservoir competence of those animals for A. bovis [17]. Besides, A. bovis can be found in many tick species (Haemaphysalis longicornis, Haemaphysalis lagrangei, Haemaphysalis concinna, and Rhipicephalus evertsi, etc.) in Asia, Europe, and Africa $[16,18]$. We detected A. bovis with a positive rate of $17.4 \%$ in $M$. ovinus for the first time, which indicated that $M$. ovinus may be the potential reservoirs or maintenance hosts of this agent. Among the Anaplasma species detected, A. phagocytophilum is an emerging zoonotic pathogen of human and animal granulocytic anaplasmosis and can be transmitted to a wide range of mammals including humans, ruminants, horses, cats, dogs, rodents, birds, and reptiles through the bite of ticks [19]. In the present study, this is the first time that A. phagocytophilum DNA has been detected in M. ovinus using the molecular biological method. Statistical analysis indicated that Aanaplasma spp. infections showed significant correlations with 
the region and altitude of the sampling sites and the co-infection. Our results expand the potential vector spectrum of $A$. bovis and $A$. phagocytophilum and emphasize the veterinary and public health significance of $M$. ovinus.

Parasitic protists of the genus Theileria, especially T. annulata, T. sergenti, and T. hirci, are the causative agent of Theileriosis and have a wide geographical and host-species distribution. Among the Theileria species, Theileria ovis mainly causes benign theileriosis in sheep and goats, which is easily overlooked [20]. Theileria ovis are distributed widely in Asia, Europe, and Africa. In China, T. ovis has mainly been reported in animal, tick, and sheep keds from Xinjiang [9,21], Inner Mongolia [22], Qinghai [23], Sichuan [24]. Several reports have recently shown that there are two species of Theileria spp. (T. ovis and T. luwenshuni) in M. ovinus [9,24]. Historically, hard ticks were considered as the only and essential vector for Theileria spp. Our findings and similar studies conducted by Zhao [9] expand the potential vector spectrum of T. ovis. Herein, a high positive rate $(89.1 \%, 82 / 92)$ of $T$. ovis DNA was demonstrated in M. ovinus in the present study, but this needs to be confirmed through more testing. Many factors including biogeography, the season of sample collection, number of samples, etc., may contribute to the differences between investigations of pathogenic organisms in M. ovinus in other regions in China or other countries.

Vector-borne pathogens including Anaplasma species, BDV, Babesia spp., Rickettsia spp., and Borrelia spp. cause economic losses in the livestock industry and pose a risk to humans. Although these infectious agents were negative in this study, some of these pathogens were found in tick, yak, and Tibetan sheep samples (unpublished data), implying that this region tends to have a higher risk of vector-borne diseases. Future studies should systematically screen for the presence of potential animal as well as human pathogens in M. ovinus.

We demonstrated the occurrence of A. ovis, A. bovis, and A. phagocytophilum, and T. ovis with veterinary and medical significance in M. ovinus in Qinghai, China. A. bovis and A. phagocytophilum was found for the first time and the present study extended the spectrum of pathogens potentially present in M. ovinus. The occurrence of these pathogens in M. ovinus may be a threat to animal and public health in the Qinghai-Tibet Plateau, China. Future investigations are warranted to elucidate the genetic diversity of vectorborne pathogens in M. ovinus and the role of M. ovinus as the specific biological vectors of some pathogens.

\section{Materials and Methods}

\subsection{Study Sites and Sample Collection}

Adult sheep keds $(\mathrm{n}=276)$ were collected at four sites: Xunhua, Haidong $(\mathrm{n}=24$, altitude $\left.3000 \mathrm{~m}, 35^{\circ} 39^{\prime} \mathrm{N} 102^{\circ} 41^{\prime} \mathrm{E}\right)$, Maqin, Golog $\left(\mathrm{n}=24\right.$, altitude $\left.3800 \mathrm{~m}, 35^{\circ} 2^{\prime} \mathrm{N} 99^{\circ} 12^{\prime} \mathrm{E}\right)$, Dari, Golog ( $\mathrm{n}=24$, altitude $\left.4100 \mathrm{~m}, 33^{\circ} 43^{\prime} \mathrm{N} 99^{\circ} 38^{\prime} \mathrm{E}\right)$, and Zhiduo, Yushu ( $\mathrm{n}=24$, altitude $4100 \mathrm{~m}, 33^{\circ} 37^{\prime} \mathrm{N} 95^{\circ} 58^{\prime} \mathrm{E}$ ) during June 2020 in Qinghai province, China (Figure 2). After collection, sheep keds were shipped into the laboratory in cooled flasks and pooled ( $\mathrm{n}=92$, three adults of the same sex collected from the same sheep were pooled) before being frozen at $-80{ }^{\circ} \mathrm{C}$ until testing. Morphological studies (Figure 2) and $18 \mathrm{~S}$ rRNA gene sequence analysis (data not shown) confirmed that the collected samples belong to sheep keds. The study was conducted in compliance with the ethical policies of the journal and the rules of the ethics committee of the Institute of Zoology, Chinese Academy of Sciences. 


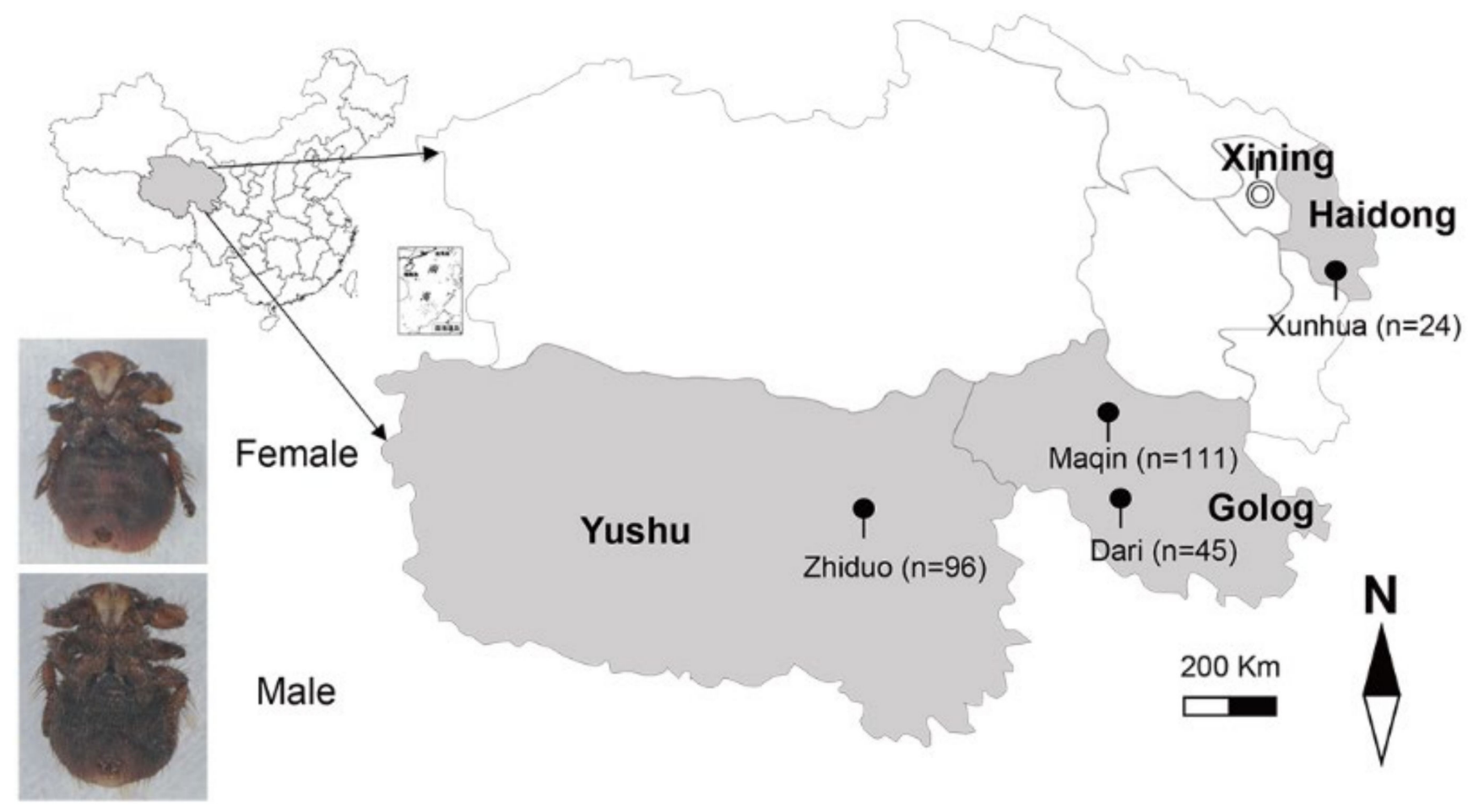

Figure 2. Sampling locations of M. ovinus $(\bullet)$ for the present survey in the Qinghai Province of China.

\subsection{Nucleic Acid Extraction and PCR Amplification}

All samples were sterilized with $70 \%$ ethanol and distilled water and were mechanically disrupted in $200 \mu \mathrm{L}$ of PBS. Genomic DNA and RNA were extracted from $100 \mu \mathrm{L}$ of the homogenate with the commercially TIANamp Genomic DNA Kit (TIANGEN BIOTECH (BEIJING) CO., LTD, Beijing, China) and Trizol reagent (Invitrogen, Carlsbad, CA, USA) according to the manufacturer's protocol. cDNA was synthesized using the GoScript Reverse Transcription System and 5'-UTR of BDV was amplified according to the Access RT-PCR System (Promega, Madison, WI, USA) [14]. Nested PCR-based amplification was employed for the detection of A. bovis, A. phagocytophilum, A. centrale, A. platys, and A. capra based on the 16S rRNA gene and the citrate synthase (gltA) gene, and conventional PCR was used for detection of $A$. ovis and A. marginale based on the msp4 gene, as previously described [16,25-27]. For piroplasm (Theileria spp. and Babesia spp.) detection, all samples were screened using nested PCR assays targeting the 18S rRNA gene [27]. Other vectorborne bacteria including Rickettsia spp. and Borrelia spp. were also detected [28-30] and the PCR primers and cycling conditions are shown in Table 3. The DNAs extracted from the domestic animals and ticks in Qinghai infected with A. ovis, A. bovis, A. phagocytophilum, Theileria ovis, Theileria sinensis, and Candidatus Rickettsia jingxinensis were used as positive controls. The PCR products were detected by $1 \%$ agarose gel electrophoresis with M5 Hipure Next III Gelred (Mei5 Biotechnology Co., Ltd., Beijing, China) stained.

\subsection{Sequencing and Phylogenetic Analysis}

The PCR products from positive samples were sequenced at BGI Sequencing (Beijing, China) and subjected to BLAST searches for nucleotide sequence analysis and alignments. Phylogenetic trees were constructed using the neighbor-joining method executed with Kimura 2-parameter model in MEGA X. Bootstrap values were assessed with 1000 bootstrap replicates. The representative nucleotide sequences of this study have been deposited in the GenBank database under accession number MW147462 for A. ovis, MW142384 for A. bovis, MW142385 for A. phagocytophilum, and MW142379 for T. ovis. 
Table 3. Primers used for vector-borne pathogens detection in M. ovinus.

\begin{tabular}{|c|c|c|c|c|c|c|c|}
\hline Pathogens & Target Gene & Methods & & Primers & Product (bp) & Annealing $\mathrm{T}\left({ }^{\circ} \mathrm{C}\right)$ & Reference \\
\hline \multirow[t]{2}{*}{ A. bovis } & \multirow[t]{2}{*}{ 16S rRNA } & PCR & $\begin{array}{l}\text { EE1 } \\
\text { EE2 }\end{array}$ & $\begin{array}{l}\text { 5'-TCCTGGCTCAGAACGAACGCTGGCGGC-3' } \\
\text { 5'-AGTCACTGACCCAACCTTAAATGGCTG-3' }\end{array}$ & 1430 & 55 & [27] \\
\hline & & $\mathrm{nPCR}^{\dagger}$ & $\begin{array}{l}\text { AB1f } \\
\text { AB1r }\end{array}$ & $\begin{array}{c}\text { 5'-CTCGTAGCTTGCTATGAGAAC-3' } \\
5^{\prime} \text {-TCTCCCGGACTCCAGTCTG-3' }\end{array}$ & 551 & 60 & [27] \\
\hline \multirow[t]{2}{*}{ A. phagocytephilum } & \multirow[t]{2}{*}{ 16S rRNA } & PCR & $\begin{array}{l}\text { EE1 } \\
\text { EE2 }\end{array}$ & $\begin{array}{l}\text { 5'-TCCTGGCTCAGAACGAACGCTGGCGGC-3' } \\
\text { 5'-AGTCACTGACCCAACCTTAAATGGCTG-3' }\end{array}$ & 1430 & 55 & [27] \\
\hline & & nPCR & $\begin{array}{l}\text { SP2f } \\
\text { SP2r }\end{array}$ & $\begin{array}{c}\text { 5'-GCTGAATGTGGGGATAATTTAT-3' } \\
\text { 5'-ATGGCTGCTTCCTTTCGGTTA-3' }^{\prime}\end{array}$ & 641 & 60 & [27] \\
\hline \multirow[t]{2}{*}{ A. centrale } & \multirow[t]{2}{*}{ 16S rRNA } & PCR & $\begin{array}{l}\text { EE1 } \\
\text { EE2 }\end{array}$ & $\begin{array}{l}5^{\prime} \text {-TCCTGGCTCAGAACGAACGCTGGCGGC-3' } \\
5^{\prime} \text {-AGTCACTGACCCAACCTTAAATGGCTG-3' }\end{array}$ & 1430 & 55 & [27] \\
\hline & & nPCR & $\begin{array}{l}\text { AC1f } \\
\text { AC1r }\end{array}$ & $\begin{array}{l}\text { 5'-CTGCTTTTAATACTGCAGGACTA-3' } \\
\text { 5'-ATGCAGCACCTGTGTGAGGT-3' }\end{array}$ & 426 & 60 & [27] \\
\hline \multirow[t]{2}{*}{ A. platys } & \multirow[t]{2}{*}{ 16S rRNA } & PCR & $\begin{array}{l}\text { EE1 } \\
\text { EE2 }\end{array}$ & $\begin{array}{l}\text { 5'-TCCTGGCTCAGAACGAACGCTGGCGGC-3' } \\
\text { 5'-AGTCACTGACCCAACCTTAAATGGCTG-3' }\end{array}$ & 1430 & 55 & [27] \\
\hline & & nPCR & $\begin{array}{l}\text { APf } \\
\text { APr }\end{array}$ & $\begin{array}{l}\text { 5'-AAGTCGAACGGATTTTTGTC-3' } \\
\text { 5'-CTTTAACTTACCGAACC-3' }^{\prime}\end{array}$ & 506 & 60 & [27] \\
\hline A. ovis & $\mathrm{msp} 4$ & PCR & $\begin{array}{l}\text { oMSP4Fw } \\
\text { oMSP4Rev }\end{array}$ & $\begin{array}{l}\text { 5'-TGAAGGGAGCGGGGTCATGGG-3' } \\
\text { 5'-GAGTAATTGCAGCCAGGGACTCT-3' }^{\prime}\end{array}$ & 347 & 62 & [26] \\
\hline A. marginale & msp4 & PCR & $\begin{array}{l}\text { mMSP4Fw } \\
\text { mMSP4Rev }\end{array}$ & $\begin{array}{c}\text { 5'-CTGAAGGGGGAGTAATGGG-3' } \\
\text { 5'-GGTAATAGCTGCCAGAGATTCC-3' }\end{array}$ & 344 & 60 & [26] \\
\hline A. capra & gltA & PCR & $\begin{array}{l}\text { Outer-f } \\
\text { Outer-r }\end{array}$ & $\begin{array}{l}\text { 5'-GCGATTTTAGAGTGYGGAGATTG-3' } \\
\text { 5'-TACAATACCGGAGTAAAAGTCAA-3' }\end{array}$ & 1031 & 55 & [25] \\
\hline & & nPCR & $\begin{array}{l}\text { Inner-f } \\
\text { Inner-r }\end{array}$ & $\begin{array}{l}\text { 5'-TCATCTCCTGTTGCACGGTGCCC-3' } \\
\text { 5'-CTCTGAATGAACATGCCCACCCT-3 }{ }^{\prime}\end{array}$ & 594 & 60 & [25] \\
\hline & 16s rRNA & PCR & $\begin{array}{l}\text { Capra-F } \\
\text { Capra-R }\end{array}$ & $\begin{array}{c}\text { 5'-GCAAGTCGAACGGACCAAATCTGT-3' } \\
\text { 5'-CCACGATTACTAGCGATTCCGACTTC-3' }^{\prime}\end{array}$ & 1261 & 60 & [26] \\
\hline Piroplasm & 18S rRNA & PCR & $\begin{array}{l}\text { Piro1-S } \\
\text { Piro3-AS }\end{array}$ & $\begin{array}{c}\text { 5'-CTTGACGGTAGGGTATTGGC-3' } \\
\text { 5'-CCTTCCTTTAAGTGATAAGGTTCAC-3' }\end{array}$ & 1410 & 55 & [27] \\
\hline & & nPCR & $\begin{array}{l}\text { PIRO-A1 } \\
\text { PIRO-B }\end{array}$ & $\begin{array}{l}\text { 5'-CGCAAATTACCCAATCCTGACA-3' } \\
5^{\prime} \text {-TTAAATACGAATGCCCCCAAC-3' }\end{array}$ & 430 & 55 & [27] \\
\hline
\end{tabular}


Table 3. Cont

\begin{tabular}{|c|c|c|c|c|c|c|c|}
\hline Pathogens & Target Gene & Methods & & Primers & Product (bp) & Annealing $\mathrm{T}\left({ }^{\circ} \mathrm{C}\right)$ & Reference \\
\hline $\mathrm{BDV} \ddagger$ & $5^{\prime}$-UTR & RT-PCR & $\begin{array}{l}\text { PBD1 } \\
\text { PBD2 }\end{array}$ & $\begin{array}{c}\text { 5'-TCGTGGTGAGATCCCTGAG-3' } \\
\text { 5'-GCAGAGATTTTTTATACTAGCCTATRC-3' }\end{array}$ & 225 & 54 & [14] \\
\hline \multirow[t]{2}{*}{ Rickettsia spp. } & $16 \mathrm{~S}$ rRNA & PCR & $\begin{array}{l}\text { Rick-16S-F3 } \\
\text { Rick-16S-R4 }\end{array}$ & $\begin{array}{l}\text { 5'-ATCAGTACGGAATAACTTTTA-3' } \\
5^{\prime} \text {-TGCCTCTTGCGTTAGCTCAC-3 }{ }^{\prime}\end{array}$ & 1284 & 58 & [28] \\
\hline & OmpA & PCR & $\begin{array}{l}\text { Rr190.70 } \\
\text { Rr190.701 }\end{array}$ & $\begin{array}{l}\text { 5'-ATGGCGAATATTTCTCCAAAA-3' } \\
\text { 5'-GTTCCGTTAATGGCAGCATCT-3' }^{\prime}\end{array}$ & 632 & 50 & {$[30]$} \\
\hline \multirow[t]{2}{*}{ Borrelia spp. } & ITS 5S-23S & PCR & $\begin{array}{l}\text { Outer23SN1 } \\
\text { Outer23SC1 }\end{array}$ & $\begin{array}{l}5^{\prime} \text {-ACCATAGACTCTTATTACTTTGAC-3' } \\
5^{\prime} \text {-TAAGCTGACTAATACTAATTACCC-3' }\end{array}$ & 380 & 52 & [29] \\
\hline & & nPCR & $\begin{array}{l}\text { Inter-23SN2 } \\
\text { Inter-23SC2 }\end{array}$ & $\begin{array}{c}\text { 5'-ACCATAGACTCTTATTACTTTGACCA-3' }^{\prime} \\
5^{\prime} \text {-GAGAGTAGGTTATTGCCAGGG-3' }\end{array}$ & 230 & 55 & [29] \\
\hline
\end{tabular}

${ }^{+}:$nested PCR; ${ }^{\ddagger}$ : Border disease virus. 


\subsection{Data Analysis}

The data were grouped into three variables in terms of sheep keds gender and the region and the altitude of the sampling sites. Differences in infection rates of each group were statistically calculated using the Chi-square test in SPSS 25.0. A $p$-value of $<0.05$ was considered significant.

Author Contributions: Conceptualization, Q.-X.Z. and H.-X.H.; Data curation, Y.L.; Formal analysis, Q.-X.Z.; Funding acquisition, H.-X.H.; Investigation, Y.W., S.-Y.H., P.-Y.Z., Z.-W.Y. and S.-L.W.; Methodology, Y.W., Y.L., S.-Y.H., B.W., G.-H.Y., P.-Y.Z., Z.-W.Y. and S.-L.W.; Project administration, H.-X.H.; Resources, Y.L., G.-H.Y., J.-Y.C. and H.-S.Z.; Visualization, X.-Q.H.; Writing—original draft, Q.-X.Z.; Writing-review \& editing, H.-X.H. All authors have read and agreed to the published version of the manuscript.

Funding: This study was financially supported by the Regular Assistance Project of International Department of the Ministry of Science and Technology of China (KY201904013), the Strategic Priority Research Program of the Chinese Academy of Sciences (XDA19050204 and XDA19090115), Beijing Innovation Consortium of Agriculture Research System (BAIC04-2020), National Forestry and Grassland Administration, China, and Beijing Wildlife Rescue Center, China.

Institutional Review Board Statement: The study was conducted in compliance with the ethical policies of the journal and the rules of the ethics committee of the Institute of Zoology, Chinese Academy of Sciences.

Informed Consent Statement: Not applicable.

Data Availability Statement: The data presented in this study are available on request from the corresponding author.

Acknowledgments: We thank the support of morphological identification of M. ovinus provided by the Qingsong Zhou.

Conflicts of Interest: The authors declare no conflict of interest.

\section{References}

1. Marcos, A.B.S.; Domenico, O. Keds, the enigmatic flies and their role as vectors of pathogens. Acta Trop. 2020, 209, 105521.

2. Rudolf, I.; Betášová, L.; Bischof, V.; Venclíková, K.; Blažejová, H.; Mendel, J.; Hubálek, Z.; Kosoy, M. Molecular survey of arthropod-borne pathogens in sheep keds (Melophagus ovinus), Central Europe. Parasitol. Res. 2016, 115, 3679-3682. [CrossRef]

3. Small, R.W. A review of Melophagus ovinus, (L.), the sheep ked. Vet. Parasitol. 2005, 130, 141-155. [CrossRef] [PubMed]

4. Sertse, T.; Wossene, A. Effect of ectoparasites on quality of pickled skins and their impact on the tanning industries in Amhara regional state, Ethiopia. Small Rum. Res. 2007, 69, 55-61. [CrossRef]

5. Liu, D.; Wang, Y.Z.; Zhang, H.; Liu, Z.Q.; Wureli, H.Z.; Wang, S.W.; Tu, C.C.; Chen, C.F. First report of Rickettsia raoultii and R. slovaca in Melophagus ovinus, the sheep ked. Parasites Vectors 2016, 9, 600. [CrossRef]

6. Chu, C.Y.; Jiang, B.G.; Qiu, E.C.; Zhang, F.; Zuo, S.Q.; Yang, H.; Liu, W.; Cao, W.C. Borrelia burgdorferi sensu lato in sheep keds (Melophagus ovinus), Tibet China. Vet. Microbiol. 2011, 149, 526-529. [CrossRef]

7. Duan, D.Y.; Liu, H.; Cheng, T.Y.; Wang, Y.Q. Microbial population analysis of the midgut of Melophagus ovinus via high-throughput sequencing. Parasites Vectors 2017, 10, 382. [CrossRef]

8. Liu, Y.H.; He, B.; Li, F.; Li, K.R.; Zhang, L.Y.; Li, X.Q.; Zhao, L. Molecular Identification of Bartonella melophagi and Wolbachia Supergroup F from Sheep Keds in Xinjiang, China. Korean J. Parasitol. 2018, 56, 365-370. [CrossRef] [PubMed]

9. Zhao, L.; Wang, J.L.; Ding, Y.L.; Li, K.R.; He, B.; Li, F.; Zhang, L.Y.; Li, X.Q.; Liu, Y.H. Theileria ovis (Piroplasmida: Theileriidae) detected in Melophagus ovinus (Diptera: Hippoboscoidea) and Ornithodoros lahorensis (Ixodida: Argasidae) removed from sheep in Xinjiang, China. J. Med. Entomol. 2020, 57, 631-635. [CrossRef]

10. Halos, L.; Jamal, T.; Maillard, R.; Girard, B.; Guillot, J.; Chomel, B.; Vayssier-Taussat, M.; Boulouis, H.J. Role of Hippoboscidae flies as potential vectors of Bartonella spp. infecting wild and domestic ruminants. Appl. Environ. Microbiol. 2004, 70, 6302-6305. [CrossRef]

11. Hornok, S.; de la Fuente, J.; Biró, N.; de Fernández, M.I.G.; Meli, M.L.; Elek, V.; Gönczi, E.; Meili, T.; Tánczos, B.; Farkas, R.; et al. First molecular evidence of Anaplasma ovis and Rickettsia spp. in keds (Diptera: Hippoboscidae) of sheep and wild ruminants. Vector Borne Zoonotic Dis. 2011, 11, 1319-1321. [CrossRef]

12. Kumsa, B.; Socolovschi, C.; Parola, P.; Rolain, J.M.; Raoult, D. Molecular detection of Acinetobacter species in lice and keds of domestic animals in Oromia Regional State, Ethiopia. PLoS ONE 2012, 7, e52377. [CrossRef]

13. Zhao, L.; He, B.; Li, K.R.; Li, F.; Zhang, L.Y.; Li, X.Q.; Liu, Y.H. First report of Anaplasma ovis in pupal and adult Melophagus ovinus (sheep ked) collected in South Xinjiang, China. Parasites Vectors 2018, 11, 258. [CrossRef] [PubMed] 
14. Liu, Y.H.; He, B.; Li, K.R.; Li, F.; Zhang, L.Y.; Li, X.Q.; Zhao, L. First report of border disease virus in Melophagus ovinus (sheep ked) collected in Xinjiang, China. PLoS ONE 2019, 14, e0221435. [CrossRef] [PubMed]

15. Battilani, M.; Arcangeli, S.D.; Balboni, A.; Dondi, F. Genetic diversity and molecular epidemiology of Anaplasma. Infect. Genet. Evol. 2017, 49, 195-211. [CrossRef]

16. Han, R.; Yang, J.F.; Mukhtar, M.U.; Chen, Z.; Niu, Q.L.; Lin, Y.Q.; Liu, G.Y.; Luo, J.X.; Yin, H.; Liu, Z.J. Molecular detection of Anaplasma infections in ixodid ticks from the Qinghai-Tibet Plateau. Infect. Dis. Poverty 2019, 8, 12. [CrossRef] [PubMed]

17. Yang, J.F.; Liu, Z.J.; Niu, Q.L.; Liu, J.L.; Han, R.; Liu, G.Y.; Shi, Y.X.; Luo, J.X.; Yin, H. Molecular survey and characterization of a novel Anaplasma species closely related to Anaplasma capra in ticks, northwestern China. Parasites Vectors 2016, 9, 603. [CrossRef]

18. Qin, X.-R.; Han, F.-J.; Luo, L.-M.; Zhao, F.-M.; Han, H.-J.; Zhang, Z.-T.; Liu, J.-W.; Xue, Z.-F.; Liu, M.-M.; Ma, D.-Q.; et al. Anaplasma species detected in Haemaphysalis longicornis tick from China. Ticks Tick Borne Dis. 2018, 9, 840-843. [CrossRef]

19. Stuen, S.; Granquist, E.G.; Silaghi, C. Anaplasma phagocytophilum-a widespread multi-host pathogen with highly adaptive strategies. Front. Cell. Infect. Microbiol. 2013, 3, 31. [CrossRef]

20. Qi, M.; Cui, Y.Y.; Song, X.M.; Zhao, A.Y.; Bo, J.; Zheng, M.L.; Ning, C.S.; Tao, D.Y. Common occurrence of Theileria annulata and the first report of T. ovis in dairy cattle from Southern Xinjiang, China. Ticks Tick Borne Dis. 2018, 9, 1446-1450. [CrossRef]

21. Li, Y.Q.; Guan, G.Q.; Ma, M.L.; Liu, J.L.; Ren, Q.Y.; Luo, J.X.; Yin, H. Theileria ovis discovered in China. Exp. Parasitol. 2011, 127, 304-307. [CrossRef]

22. Yang, Y.; Mao, Y.J.; Kelly, P.; Yang, Z.P.; Luan, L.; Zhang, J.L.; Li, J.; EI-Mahallawy, H.S.; Wang, C.M. A pan-Theileria FRET-qPCR survey for Theileria spp. in ruminants from nine provinces of China. Parasites Vectors 2014, 7, 413. [CrossRef] [PubMed]

23. Li, J.X.; Jian, Y.N.; Jia, L.J.; Galon, E.M.; Benedicto, B.; Wang, G.P.; Cai, Q.G.; Liu, M.M.; Li, Y.C.; Ji, J.W.; et al. Molecular characterization of tick-borne bacteria and protozoans in yaks (Bos grunniens), Tibetan sheep (Ovis aries) and Bactrian camels (Camelus bactrianus) in the Qinghai-Tibetan Plateau Area, China. Ticks Tick Borne Dis. 2020, 11, 101466. [CrossRef]

24. Hao, L.L.; Yuan, D.B.; Li, S.H.; Jia, T.; Guo, L.; Hou, W.; Lu, Z.P.; Mo, X.; Yin, J.; Yang, A.G.; et al. Detection of Theileria spp. in ticks, sheep keds (Melophagus ovinus), and livestock in the eastern Tibetan Plateau, China. Parasitol. Res. 2020, 119, 2641-2648. [CrossRef]

25. Li, H.; Zheng, Y.-C.; Ma, L.; Jia, N.; Jiang, B.-G.; Jiang, R.-R.; Huo, Q.-B.; Wang, Y.-W.; Liu, H.-B.; Chu, Y.-L.; et al. Human infection with a novel tick-borne Anaplasma species in China: A surveillance study. Lancet Infect. Dis. 2015, 15, 663-670. [CrossRef]

26. Torina, A.; Agnone, A.; Blanda, V.; Alongi, A.; D’Agostino, R.; Caracappa, S.; Marino, A.M.F.; Marco, V.D.; de la Fuente, J. Development and validation of two PCR tests for the detection of and differentiation between Anaplasma ovis and Anaplasma marginale. Ticks Tick Borne Dis. 2012, 3, 283-287. [CrossRef]

27. Wang, H.N.; Yang, J.F.; Mukhtar, M.U.; Liu, Z.J.; Zhang, M.H.; Wang, X.L. Molecular detection and identification of tick-borne bacteria and protozoans in goats and wild Siberian roe deer (Capreolus pygargus) from Heilongjiang Province, northeastern China. Parasites Vectors 2019, 12, 296. [CrossRef]

28. Anstead, C.A.; Chilton, N.B. A novel Rickettsia species detected in vole ticks (Ixodes angustus) from Western Canada. Appl. Environ. Microbiol. 2013, 79, 7583-7589. [CrossRef]

29. Rijpkema, S.G.; Molkenboer, M.J.; Schouls, L.M.; Jongejan, F.; Schellekens, J.F. Simultaneous detection and genotyping of three genomic groups of Borrelia burgdorferi sensu lato in Dutch Ixodes ricinus ticks by characterization of the amplified intergenic spacer region between 5 S and 23 S rRNA genes. J. Clin. Microbiol. 1995, 33, 3091-3095. [CrossRef]

30. Roux, V.; Fournier, P.E.; Raoult, D. Differentiation of spotted fever group rickettsiae by sequencing and analysis of restriction fragment length polymorphism of PCR-amplified DNA of the gene encoding the protein rOmpA. J. Clin. Microbiol. 1996, 34, 2058-2065. [CrossRef] 